\title{
Application of the New Jersey Department of Environmental Protection Water Budget Manual to Finderne Farms Wetland Mitigation and Assessment of Project Performance
}

\author{
Roy C. Messaros \\ Coastal and Hydraulic Engineer, U.S. Army Corps of Engineers, New York District, 26 Federal Plaza, New York, NY 10278-0090, USA \\ Correspondence should be addressed to Roy C. Messaros; roy.c.messaros@usace.army.mil
}

Received 16 May 2013; Revised 13 August 2013; Accepted 15 August 2013

Academic Editor: Wen-Cheng Liu

Copyright (C) 2013 Roy C. Messaros. This is an open access article distributed under the Creative Commons Attribution License, which permits unrestricted use, distribution, and reproduction in any medium, provided the original work is properly cited.

\begin{abstract}
The U.S. Army Corps of Engineers, NY District's wetland mitigation proposal for Finderne Farms in Bridgewater, NJ, was approved in August 2005 by the state regulatory agency. The design goal was to provide mitigation for wetlands impacted by the Green Brook Flood Control project at a ratio of $2: 1$. As part of the design process in 2001, the available historical hydrologic data was evaluated. At that time, the NJ Department of Environmental Protection (NJDEP) Water Budget Manual was not available as a tool for accessing an acceptable design hydroperiod. Construction of the Finderne mitigation site was completed in July 2006. A sixyear postconstruction monitoring program has determined that certain areas at the site have not achieved the established wetland success criteria. In 2012, there was a $28 \%$ survival of planted woody vegetation and a $74 \%$ cover of invasive species within Creation Area 1, a palustrine forested wetland. With the advent of the Water Budget Manual, a reevaluation of the historical hydrologic data was performed. Based on this analysis, the hydroperiod and soil moisture conditions are not representative of sustainable wetlands. Adaptive management measures are currently being developed and evaluated to improve the hydrology, hydric soil conditions, and survival of target vegetation at the Finderne site.
\end{abstract}

\section{Introduction}

1.1. Wetland Mitigation. Throughout most of the last two centuries, the federal government has encouraged or subsidized conversion of wetlands to other land uses, especially agricultural use. Since the 1970s this policy has been reversed but not before significant amounts of wetlands have been lost. The net loss of wetlands from the mid-1950s to the mid1970 s was 184,100 hectares/year [1]. Wetlands are continually being threatened by competing land use interests. Wetland mitigation is the creation, restoration, and enhancement for the purpose of providing compensatory mitigation in advance of authorized impacts to similar resources. Within the past two decades mitigation has evolved from an infrequently used term to a heavily applied wetland management practice for those who are responsible for the dual function of protecting wetlands and permitting future development [2]. In 1990 a memorandum of agreement between the U.S. Army
Corps of Engineers (USACE) and the U.S. Environmental Protection Agency (EPA) was signed, reestablishing guidelines to achieve a national goal of no overall net loss of wetland functions and values. Successful mitigation efforts are crucial when wetland functions and values are lost after a wetland area has been altered or converted for other land uses. The success of a mitigation project depends in large part on the selection of appropriate compensatory wetland mitigation sites. A survey of past mitigation projects nationwide indicates that the overall success rate of permitlinked mitigation projects remains low [2]. Eliot [3] reviewed 58 mitigation projects in San Francisco Bay that had been permitted over a six-year period and determined that they did not adhere to the established mitigation policies and were frequently unsuccessful with almost half of these projects not meeting the specified permit completion date. Under present mitigation policies and practices, mitigation has a high chance of failure [4], and reporting restoration projects 
may be pivotal for establishing baselines and achieving success for future efforts [5]. Inadequate design of wetland hydrology, improper location, incorrect elevation, poor soil characteristics, invasive plant species, and exposure to severe storms have led to limited success and poor performance [2].

Current wetland mitigation practices do not fully recover wetland function often as a result of poor site selection [6]. Quammen [7] reviewed studies of mitigation projects in various parts of the country, including New England, New Jersey, Virginia, Florida, and the San Francisco Bay area. It was concluded that compliance with permit conditions was low and that effectiveness of restoration to compensate for wetland losses has been difficult to determine. Quammen [7] noted that only when the project objectives and design criteria are clearly stated as part of the permit conditions and monitoring is conducted and reported is it possible to evaluate whether created wetlands are able to compensate for the losses in natural wetlands. A New Jersey field survey and qualitative evaluation of 30 artificial salt marsh projects revealed an array of issues including sedimentation problems and unplanned shifts in species composition that hindered the mitigation success [8]. Additional detailed quantitative sampling at eight of the sites indicated significant differences in nearly all sediment characteristics and vegetation parameters when compared to adjacent natural salt marshes. Wetland hydrology is perhaps the most critical element in any wetland mitigation project. Many wetland scientists have referred to wetland hydrology as the most important component of wetland ecosystems $[9,10]$. Despite the significance of wetland hydrology, it is often inadequately defined for mitigation projects. It remains a difficult challenge to adequately address the restoration of wetland hydrology because there are many unknown or poorly understood variables that influence the water budget.

1.2. Finderne Farms. The U.S. Geological Survey (USGS) map shows the Finderne Farms wetland mitigation site located in the Township of Bridgewater in Somerset County, New Jersey, along the left overbank of the Raritan River (Figure 1). Situated south of the New Jersey State Highway Route 28, west of Finderne Avenue, this 52.60 hectare (ha) site is bound to the south, east, and west by the Raritan River. On August 5, 2005, the NJDEP, Division of Land Use Regulation Program (LURP) approved the USACE, New York District's wetland mitigation proposal, titled, "Wetland Mitigation Design for the Finderne Site, Green Brook Flood Control Project, Bridgewater Township, Somerset County, New Jersey." The Finderne site serves as off-site wetland habitat mitigation for the environmental impacts of the Bound Brook levee/floodwall construction elements, Segments R, T, and U, of the Green Brook Flood Control Project (a USACE Flood Risk Management Project). The Green Brook Project is designed to reduce flood damage in a portion of New Jersey's Raritan River Basin in the north-central part of the state in Middlesex, Somerset, and Union counties. The land at the Finderne site was used for agriculture and raising livestock from the late 1600s until purchased by Somerset County (ca. 2000) for open space preservation and park development.
The Finderne site is predominantly fluvial at a relatively uniform elevation of $10.06 \mathrm{~m}$ (NGVD 1929). Current features include the Van Veghten House historic building located along the northern border of the site. Several easements are located on the property, including a 0.40 ha area set aside by Somerset County Parks as green acres land, a trunk sewer line right-of-way for the Somerset-Raritan Valley Sewer Authority, and a gas and electric company utility right-ofway.

The overall design goal of the mitigation plan was to provide in-kind mitigation for wetlands impacted by the Green Brook Project at a minimum ratio of $2: 1$. The mitigation plan was developed to provide 20.13 ha of modified or constructed wetlands. The specific wetland areas are shown in Figure 2 and include:

(1) creation of 9.15 ha of palustrine forested wetland (C1, $\mathrm{C} 2$, and $\mathrm{C} 3$ ),

(2) enhancement of 4.86 ha of forested wetland (E1, E4$\mathrm{E} 7$, and $\mathrm{EC1}$ ),

(3) enhancement of 2.35 ha of scrub-shrub wetland (E2),

(4) enhancement of 2.23 ha of emergent wetland (E3),

(5) preservation of 1.54 ha of palustrine emergent wetland/open water (E8, E9).

Construction of the Finderne mitigation site was completed in July 2006. To ensure compliance with the USACE policy and the NJDEP wetland mitigation regulations, the Finderne site was monitored for six full growing seasons. The National Resources Conservation Service (NRCS) defines the growing season as the portion of the year during which soil temperatures are above $5^{\circ} \mathrm{C}$ at a depth of $50 \mathrm{~cm}$ below the soils surface [11]. For New Jersey this is approximately the period between March and October. A hydroperiod is the seasonal pattern of the water level that approximates the hydrologic signature of each type of wetland [10]. An adequate hydroperiod will occur if a balanced water budget is maintained for the growing season, meaning that the availability of water will not be the limiting factor for target wetland plant sustainability. Wetland hydrology is a critical component of the success of mitigation projects [12]. This postconstruction monitoring program has determined that the site has not achieved the established wetland success criteria. As part of the design process completed in 2001, the available historical (1972-2001) hydrologic data was analyzed. At that time the NJDEP Water Budget Manual was not available. As a followup analysis the Water Budget Manual was applied and this historical hydrologic data was reevaluated.

As part of the mitigation design in 2001, a hydrologic study was performed which included a preliminary groundwater investigation, an assessment of off-site runoff draining to the site, and a hydraulic analysis of Raritan River flood characteristics. The hydraulic analysis included identification of the minimum flood stage (and associated recurrence interval) that would result in left overbank flow from the Raritan River and inundate the Finderne site. The hydrologic and hydraulic analyses for the original design process completed in 2001 concluded the following. 


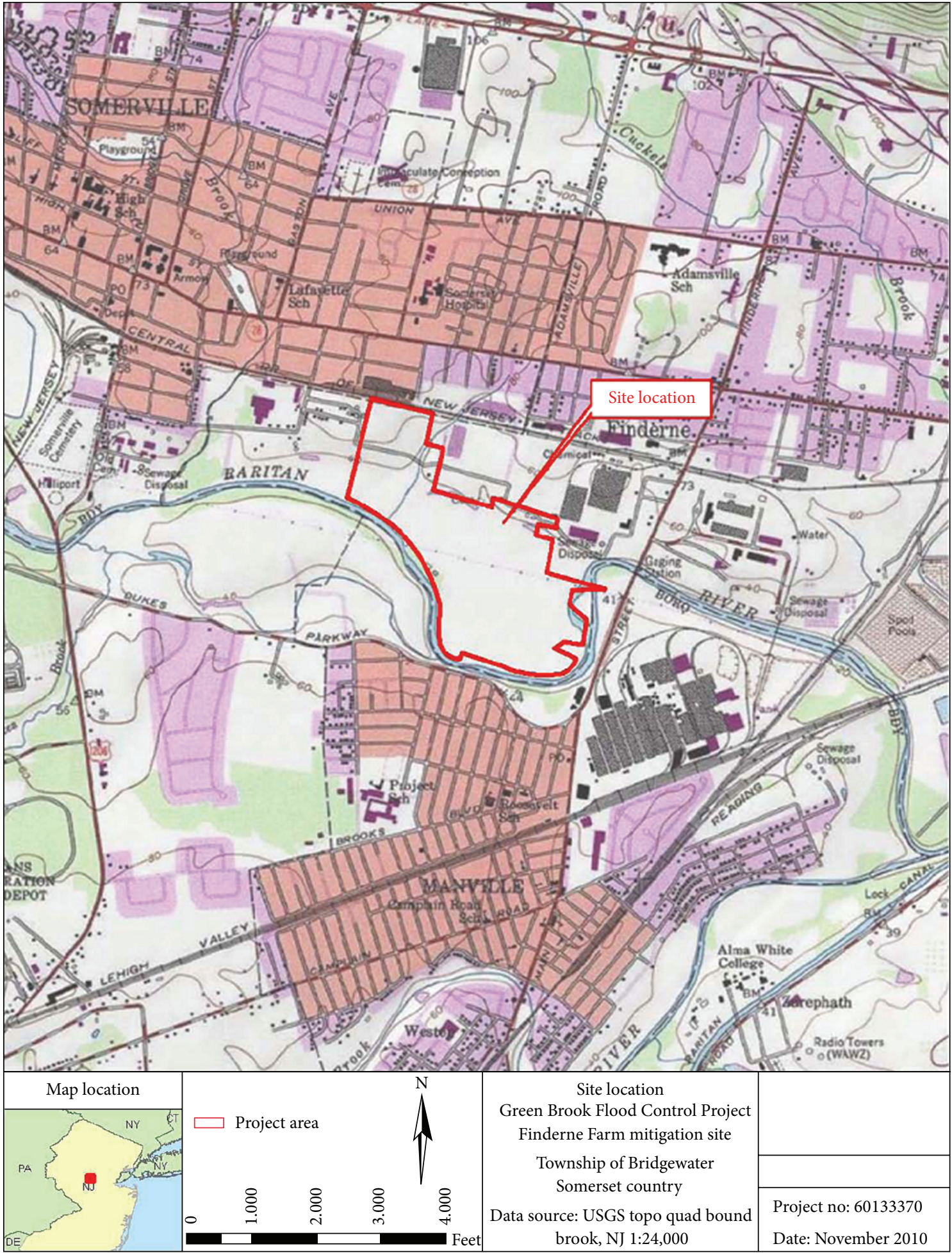

FIGURE 1: USGS topographic quadrangle map of Bound Brook, NJ.

(i) Direct precipitation and overbank flow are the two primary hydrologic inputs for the site.

(ii) The depth to groundwater observed at the site suggested that the groundwater at a sufficient depth below the ground surface does not represent a reliable water supply to support wetland hydrology. Groundwater regression analysis predicted a seasonal high groundwater at $1.5 \mathrm{~m}$ below the ground surface. The regression analysis was developed based on data 


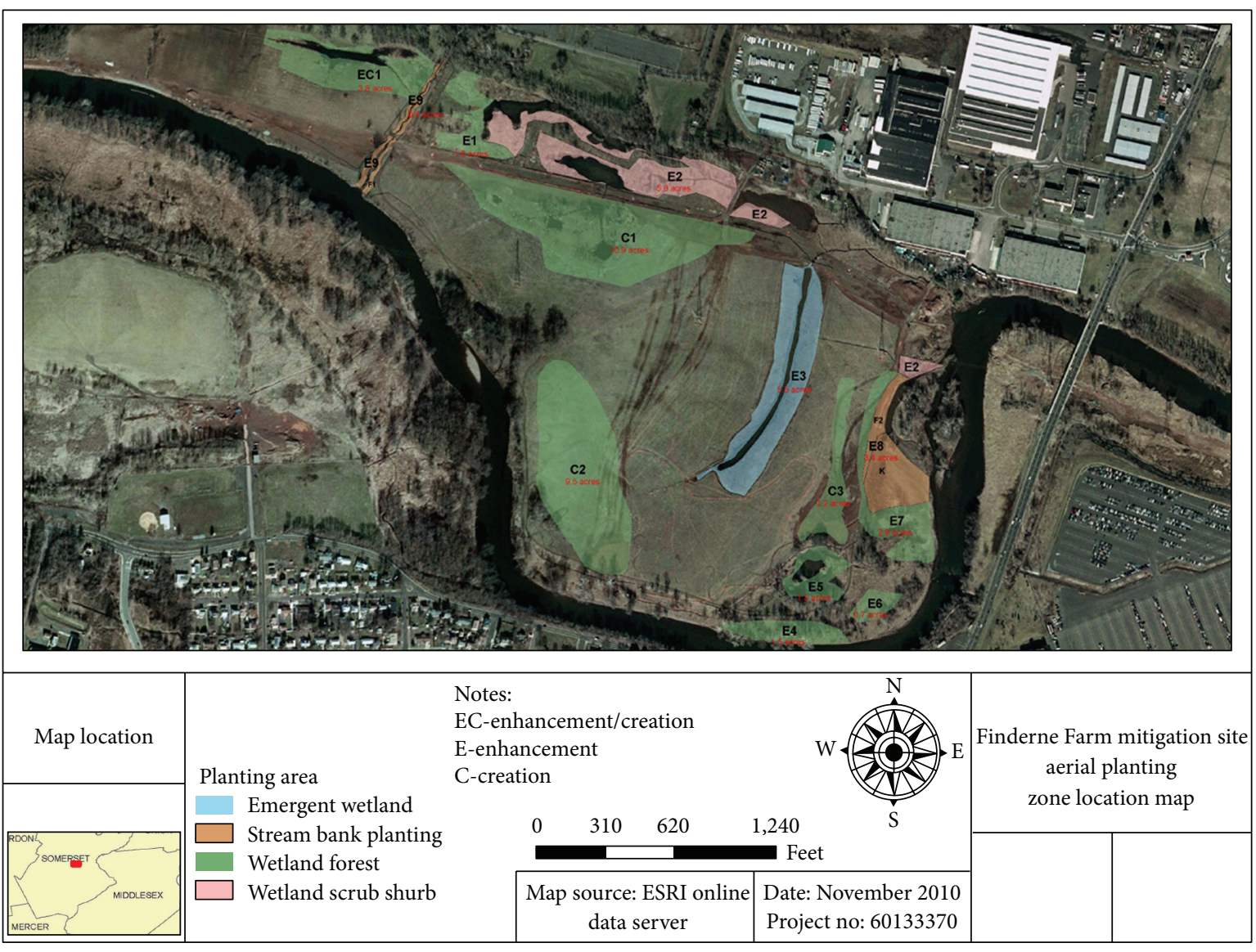

FIGURE 2: Finderne Farms mitigation site aerial planting zone location map.

collection from 1998 to 1999, which encompassed a period of low rainfall (approximately $11.7 \mathrm{~cm}$ below normal) during the early growing season. Soils in the Rowland series (which dominate the Finderne site) reportedly have a seasonal high groundwater up to $0.9 \mathrm{~m}$ below ground surface, which is considerably higher than that suggested, based on the groundwater regression analysis and hand-auger results.

(iii) Surface runoff from off-site areas was determined to be a negligible source under premitigation conditions.

The major component of water input comes from precipitation but is not retained at the site for adequate periods of time given the soil conditions. There are reported instances with overbank flow from the Raritan River, but since the soil condition is permeable, the water is not retained and lost through seepage. Data from 1970 through 2000 was analyzed, and based on the hydraulic modeling, the Raritan River flow required to overtop the average left bank height of $10.7 \mathrm{~m}$ at the Finderne site was $283.4 \mathrm{~m}^{3} / \mathrm{s}$. This analysis of overbank flow at the Finderne site between March and June in any given year raises certain questions about the adequacy for the overall water budget.

This analysis focuses on Creation Area 1 (C1), 3.82 ha of palustrine forested wetland, since the original mitigation design completed in 2001 was limited to the hydrology at C1.
This forested wetland creation area was designed to provide sufficient flood storage from the Raritan River for approximately 7 to 10 days of inundation followed by 7 to 11 days of soil saturation within the upper $30.5 \mathrm{~cm}$ of the soil profile during the growing season. The goal of the planting activity was to create a palustrine forested wetland with a moderate to dense shrub layer. Bare root or tree stock of Quercus bicolor (swamp white oak), Quercus phellos (willow oak), Fraxinus pennsylvanica (green ash), Platanus occidentalis (American sycamore), Quercus palustris (pin oak), and Nyssa sylvatica (black gum) were installed at a density of 1680 trees per hectare at 2.4 meters off center. The shrub stratum was created by installing Clethra alnifolia (coastal sweet pepperbush), Cornus amomum (silky dogwood), Vaccinium corymbosum (highbush blueberry), and Viburnum dentatum (southern arrowwood) at a density of 479 shrubs per hectare at 4.6 meters off center.

\section{Methods}

2.1. Hydrology. A water budget is an accounting of the balance between water inputs (precipitation, surface water inflow, and ground water inflow) and water outputs (evapotranspiration, surface water outflow, and ground water outflow). Any difference between total inflow and total outflow from a wetland represents a change in storage. A water budget 
serves as a valuable tool for understanding the hydrologic processes that occur in a given ecological system because it quantifies each of the individual components of a wetland's hydrologic cycle and provides insight into the effects of potential or planned changes to the system. Herein is the application of the NJDEP Water Budget Manual to the hydrologic data analysis for the Finderne site. The fundamental concepts and governing equations described in the NJDEP Water Budget Manual are based on Pierce [13] and include applicable models as well as methods and requirements for the determination of all constituents of the water budget. The intent of this effort was to demonstrate the application of the Water Budget Manual and focus on the graphical presentation of hydrologic analysis rather than a review of the manual. The complete details of the methodology are available in the Water Budget Manual and it is recommended for further reading. In the context of a wetland water budget, the term Hydrologic Continuity Equation will be used since the concern is the conservation (i.e., continuity) of volume. The water budget is a balance between inputs and outputs resulting in a change in storage and/or water surface elevation at the site. The model for Hydrologic Continuity is given in (1) and is consistent with the NJDEP Water Budget Manual:

$$
\Delta S=P+\mathrm{SWI}+\mathrm{GWI}-\mathrm{ET}-\mathrm{SWO}-\mathrm{GWO}+\text { residual, }
$$

where $\Delta S$ is the change in storage, $P$ is the precipitation, SWI is the surface water inflow, GWI is the ground water inflow, ET is the evapotranspiration, SWO is the surface water outflow, GWO is the ground water outflow (including seepage); and residual is the uncertainty inherent in any model; instrumentation, measurements and so forth, includes remaining unbalanced quantities.

Residuals include the remaining unbalanced quantities that can only be accounted for through uncertainty (i.e., error in instrumentation and measurements). Wang et al. [14] provided a thorough explanation of residual analysis which can be achieved when quantities of input $(P, \mathrm{SWI}$, and GWI) and output (ET, SWO, GWO/Seepage) are adequately measured and quantified. Mitsch et al. [15] reported an experimental wetland study at the Olentangy River Wetland Research Park where quantities for all input and output were accurately measured. Using (1), Mitsch et al. [15] calculated a value for the "residual" quantity since all other quantities (including change in storage) were measured, and given Hydrologic Continuity (1), the balanced equation resulted in a value for the residual.

2.2. Vegetation Monitoring. Based on NJDEP mitigation requirements, a monitoring methodology was developed to document the following parameters.

(i) Planted vegetation, as well as target hydrophytes which are naturally colonizing (recruitment), is progressing toward $85 \%$ survival or $85 \%$ area coverage. In forested wetland mitigation areas, woody species are thriving, increasing in stem density and height each year. (ii) Development of hydric soils within mitigation areas.

(iii) The hydrologic regime as specified in the mitigation proposal is present. Forested wetland mitigation areas were designed and constructed to mimic a seasonally flooded hydrologic regime. Seasonally flooded wetlands typically have surface water present for extended periods during the growing season, but surface water is absent by the end of the growing season.

(iv) Less than $10 \%$ of the mitigation area is occupied by invasive or noxious species.

Vegetation was assessed in both spring and fall to document conditions that indicate if there is at least $85 \%$ coverage of planted vegetation or target hydrophytes or to show a trend toward potential success. Six-meter radius circular plot sampling was conducted with plot locations selected using a simple random sampling procedure. The field biologist would begin by walking to the edge of a planting area. Using a table of sets of random site selection directions, the biologist would choose a number from 1 to 100 . The chosen number would be located on the table, and then the biologist would follow the instructions on the table describing the amount of steps to be taken in each direction. From the first plot, the planting area would be traversed for a random distance. A second sampling plot would then be chosen by using the table of random site selection directions. Data recorded at each monitoring plot in spring and fall for woody and invasive species was based on percent plant cover. Additional data included whether the species was planted or was a recruit (naturally colonizing native species), number of live plants (survival), height, and plant health.

\section{Results}

3.1. Hydrology. Based on the 2001 Design Report, the following determinations are made.

(1) GWI is neglected, no significant contribution.

(2) SWO is neglected, no significant outflow volume.

(3) GWO is loss due to seepage (i.e., percolation) of water into the soil.

(4) SWI represents runoff from a drainage area of 8.42 ha into 3.82 ha of created forested wetland and does not include Raritan River overbank flow.

Equation (1) therefore reduces to (2) for the Finderne water budget.

$$
\Delta S=P+\mathrm{SWI}-\mathrm{ET}-\mathrm{GWO}+\text { residual } .
$$

The change in storage $(\Delta S)$ is the mathematical sum of precipitation, SWI, ET, and seepage (GWO). The change in storage incorporates the major components (inputs/outputs) and excludes any minor components assuming there is no appreciable SWO or GWI. Although (2) includes residuals, there is inadequate data available from the 2001 Design Report to accurately assess this parameter. A value for 
the residual is possible only when all known input/outputs and change in storage have been measured and quantified. Residual is presented in (2) to acknowledge that all modeling has uncertainty. The Water Budget Manual includes an Excel spreadsheet that was developed by Pierce [13]. The intent of this spreadsheet is to create a composite wetland hydrograph (i.e., water budget) with a change in storage volume from month to month. Negative values for the change in storage are acceptable as they indicate lack of water or deficit. The larger the negative value, the greater the deficit of water at the Finderne site.

The objective of this reevaluation for the 2001 Design Report data was to examine four different hydrologic water budget scenarios based on the years of record specified as follows:

(1) average conditions for years of record (1972-2001),

(2) wet year of record (1975),

(3) dry year of record (1976),

(4) average of three most recent years (1999-2001).

The Water Budget Manual was applied, and the hydrographs will help illustrate the degree of suitability for the hydroperiod at the Finderne site. Precipitation data in the 2001 Design Report was obtained from the USGS Bound Brook, NJ weather station and pan evaporation data from New Brunswick, NJ weather station. The surface water inflow data from the design report is based on runoff from an area of 8.42 ha draining into a 3.82 ha portion of the forested palustrine wetland $\mathrm{C}$. Although this creation area has a swale to help convey Raritan River overbank flow into the site, there is no measurable contribution present in this data. The total Finderne site is 52.60 ha and has 20.13 ha of actual wetland mitigation area.

(1) Average Conditions for Years of Record (1972-2001). The hydrologic water budget with average monthly values for the years of record for precipitation $(P)$, surface water inflow (SWI), evapotranspiration (ET), seepage (GWO), and change in storage $(\Delta S)$ are presented in Figure 3. The average change in storage is $1.8 \mathrm{~cm} / \mathrm{month}$ during the growing season (March-October) and is $1.4 \mathrm{~cm} / \mathrm{month}$ in June corresponding to the peak in growing season when evapotranspiration is at a maximum of $12.7 \mathrm{~cm} /$ month. The average for the years is $2.9 \mathrm{~cm} / \mathrm{month}$. The annual average evapotranspiration is $6.1 \mathrm{~cm} / \mathrm{month}$ with the minimum occurring in January and December at $0.5 \mathrm{~cm} /$ month. The amount of seepage (averaging $3.8 \mathrm{~cm} / \mathrm{month}$ ) is a function of soil type and the precipitation (averaging $9.6 \mathrm{~cm} / \mathrm{month}$ ); the more the precipitation, the greater the availability for loss due to percolation. The average monthly seepage during the growing season is $2.9 \mathrm{~cm} /$ month and is $1.2 \mathrm{~cm} /$ month for the peak in growing season. The total annual precipitation is $115 \mathrm{~cm}$ for the years of record (1972-2001) and ranges from a monthly average of $6.5 \mathrm{~cm} /$ month in February to $12.0 \mathrm{~cm} / \mathrm{month}$ in July. The total annual surface water inflow is $37.9 \mathrm{~cm}$ and represents $24.8 \%$ of the total input for the water budget with precipitation representing $75.2 \%$.

(2) Wet Year of Record (1975). The hydrologic water budget for the wet year of record (1975) is given in Figure 4. Although the annual average for change in storage is $2.7 \mathrm{~cm} / \mathrm{month}$ for the wet year of record and is comparable to $2.9 \mathrm{~cm} / \mathrm{month}$ for the average years of record (1972-2001), the former has positive storage for May, June, and July, 4.1, 6.6, $10.9 \mathrm{~cm} /$ month, respectively. The average change in storage over the growing season (March-October) is $3.0 \mathrm{~cm} / \mathrm{month}$ for the wet year of record which is higher than the average years of record $(1.8 \mathrm{~cm} / \mathrm{month})$. Evapotranspiration peaks in June with $15.0 \mathrm{~cm} / \mathrm{month}$ and is similar to the average years of record of $12.7 \mathrm{~cm} / \mathrm{month}$ in June as shown in Figure 3. This peak in evapotranspiration occurring in June is indicative of the peak in the growing season. The average monthly seepage of $9.4 \mathrm{~cm} /$ month for the wet year is proportional to the precipitation, averaging $13.6 \mathrm{~cm} / \mathrm{month}$. The average monthly seepage during the growing season is $9.5 \mathrm{~cm} / \mathrm{month}$ and peaks at $10.1 \mathrm{~cm} / \mathrm{month}$ in June. Notice that the highest monthly average precipitation of $30.2 \mathrm{~cm} / \mathrm{month}$ in July corresponds to the peak in seepage of $22.1 \mathrm{~cm} / \mathrm{month}$ which indicates the coupling between these two parameters. The total annual precipitation is $163 \mathrm{~cm}$ for the wet year of record and ranges from a monthly average of $6.0 \mathrm{~cm} / \mathrm{month}$ in April to $30.2 \mathrm{~cm} /$ month in July. The wet year of record was defined in this analysis as the largest total precipitation received at the site for January to December. The total averaged annual surface water inflow is $67.3 \mathrm{~cm}$ and represents $29.2 \%$ of the total input for the water budget with precipitation representing $70.8 \%$.

(3) Dry Year of Record (1976). The hydrologic water budget for the dry year of record (1976) is given in Figure 5. The annual average change in storage is $1.2 \mathrm{~cm} /$ month for the dry year as compared to $2.7 \mathrm{~cm} / \mathrm{month}$ and $2.9 \mathrm{~cm} / \mathrm{month}$ for the wet year and average years of record, respectively. The change in storage is positive for a total of only four months that include January $(6.0 \mathrm{~cm} / \mathrm{month})$ and October to December $(17.5,0.3$, $5.52 \mathrm{~cm} /$ month, resp.). The change in storage is a deficit for the critical period of the growing season (April to September) with $2.2 \mathrm{~cm} /$ month. The average change in storage over the growing season (March-October) is $0.5 \mathrm{~cm} / \mathrm{month}$ for the dry year of record. The evapotranspiration peaks in June (11.6 cm/month) which is consistent with the prior two conditions (average conditions, $12.7 \mathrm{~cm} /$ month, Figure 3 and wet year, $15.0 \mathrm{~cm} / \mathrm{month}$, Figure 4$)$. The loss due to seepage is zero from April to December as a function of a change in storage deficit and evapotranspiration drawing the available moisture from the system. The total annual precipitation is $96 \mathrm{~cm}$ for the dry year of record with an average monthly precipitation of $7.2 \mathrm{~cm} /$ month, ranging from $0.6 \mathrm{~cm} / \mathrm{month}$ to $16.0 \mathrm{~cm} / \mathrm{month}$. The dry year of record was defined in this analysis as the smallest total precipitation received at the site for January to December. The total averaged annual surface water inflow is $1.9 \mathrm{~cm}$ and represents $20.5 \%$ of the total input for the water budget with precipitation representing $79.5 \%$. 


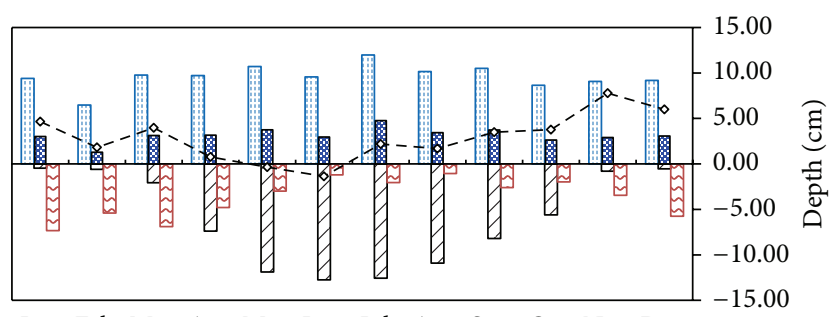

Jan. Feb. Mar. Apr. May. June July Aug. Sept. Oct. Nov. Dec. Months

$$
\begin{array}{ll}
\text { Precipitation } & \text { Surface water inflow } \\
\text { ET } & -\diamond-\Delta S \\
\text { Seepage } &
\end{array}
$$

FIGURE 3: Finderne wetland mitigation average condition, 19722001.

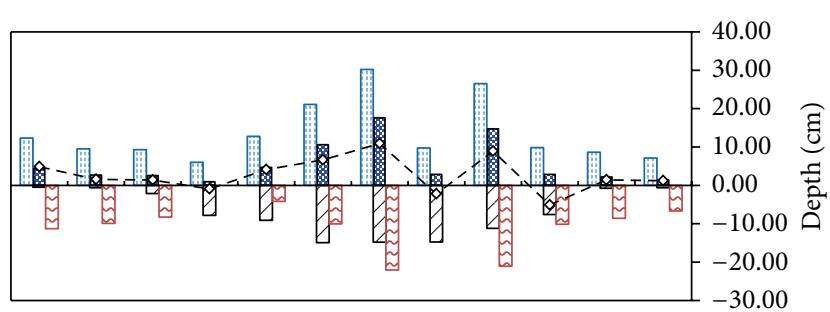

Jan. Feb. Mar. Apr. May. June July Aug. Sept. Oct. Nov. Dec.

$$
\begin{aligned}
& \text { Months } \\
& \text { Surface water inflow } \\
& -\diamond-\Delta S
\end{aligned}
$$

ET

and Seepage

FIGURE 4: Finderne wetland mitigation wet year (1975).

(4) Average of Three Most Recent Years (1999-2001). The hydrologic water budget for the three most recent years of historical data (1999-2001) is given in Figure 6. The annual average change in storage is $2.8 \mathrm{~cm} /$ month and is comparable to the wet year and average years of record. The average change in storage for the growing season is $1.6 \mathrm{~cm} / \mathrm{month}$ and is essentially the same as the average conditions (19722001) of $1.8 \mathrm{~cm} /$ month. Evapotranspiration peaks in May with $12.4 \mathrm{~cm} /$ month $(11.6 \mathrm{~cm} /$ month in June $)$ and is very similar to the peak of $12.7 \mathrm{~cm} /$ month occurring in June for the average years of record. The annual average for evapotranspiration is $5.8 \mathrm{~cm} / \mathrm{month}$ and is comparable to $6.1 \mathrm{~cm} / \mathrm{month}$ for the average years of record. The lost from seepage for the three most recent years averages $3.2 \mathrm{~cm} /$ month and is comparable to the historical average of $3.8 \mathrm{~cm} / \mathrm{month}$, while the dry year is $1.8 \mathrm{~cm} /$ month and the wet year is $9.4 \mathrm{~cm} / \mathrm{month}$. The total annual precipitation is $107 \mathrm{~cm}$ for the three most recent years and averages $9.0 \mathrm{~cm} /$ month. The total annual surface water inflow is $33.9 \mathrm{~cm}$ and represents $24.1 \%$ of the total input for the water budget with precipitation representing $75.9 \%$. These percentages compare favorably with the average years of record but the total for surface water inflow and precipitation is less; $33.9 \mathrm{~cm}$ versus $38.0 \mathrm{~cm}$ for inflow and $107 \mathrm{~cm}$ versus $115 \mathrm{~cm}$ for precipitation three most recent years and average years of record, respectively. Based on these recent years of

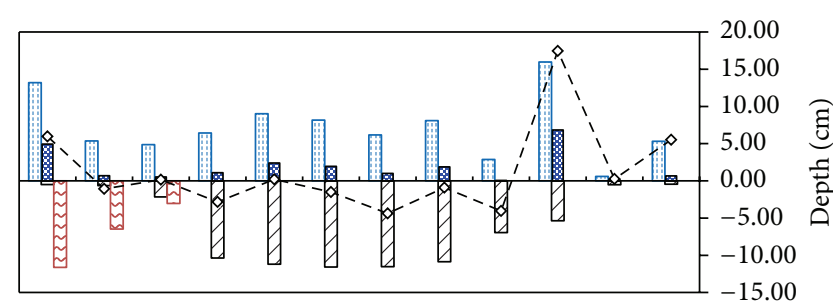

Jan. Feb. Mar. Apr. May. June July Aug. Sept. Oct. Nov. Dec. Months

$$
\begin{array}{ll}
\text { Precipitation } & \text { Surface water inflow } \\
\text { ET } & -\diamond-\Delta S \\
\text { Seepage } &
\end{array}
$$

FIGURE 5: Finderne wetland mitigation dry year (1976).

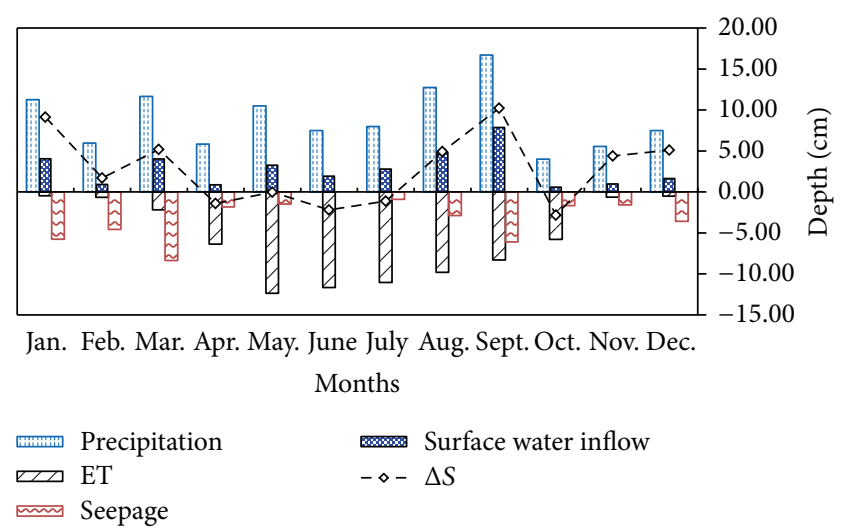

FIGURE 6: Finderne wetland mitigation recent years, 1999-2001.

record there may be less water getting to the site than in previous years.

3.2. Vegetation Monitoring. Spring vegetation surveys were conducted in late May and fall surveys were conducted in mid-October for each year during the six year monitoring period (2007-2012). For all monitoring periods (spring and fall, 2007-2012) there were six plots surveyed at C1. Each year is an average of spring and summer observations. The random sampling procedure was used to determine the percent of plant cover of target species, number of live plants, height, and frequency of planted and recruited woody stems for C1. Recruits include, but are not limited to, trees, for example, Acer saccharinum (silver maple) and Salix nigra (black willow) and shrubs, for example, Cornus stolonifera which are native to the region. Figure 7 illustrates the results for the percent of target species with percent of survival of planted material (trees and shrubs). Figure 7 also includes the percent of herbaceous invasive species observed at C1.

The percent target species decreased the first year (20062007 ) to $68 \%$ survival and a corresponding $49 \%$ planted material survival. For this first year (2007) of monitoring a $32 \%$ cover of invasive plants was recorded. The decline in target plant cover has been progressing, and in 2012 there was $26 \%$ survival with an observed corresponding $28 \%$ planted material survival. Over the four year period from 2008 to 


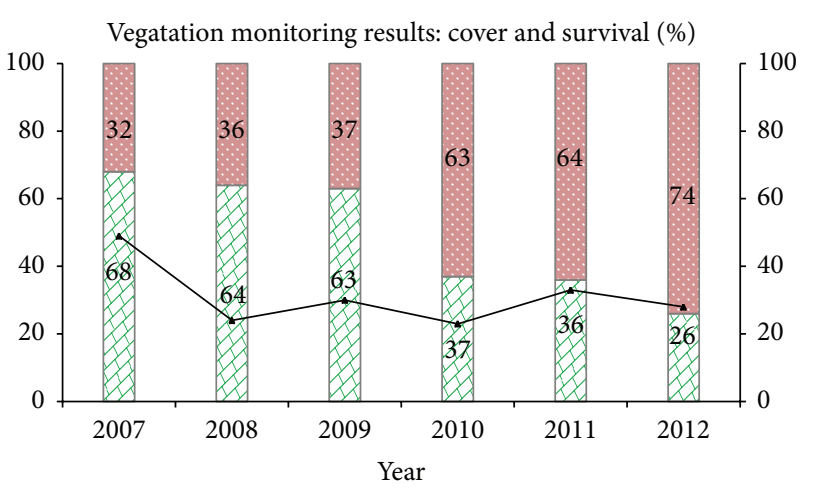

$\square$ Percent target species
$\ldots$ Percent invasive species
$\square$ Percent survival of planted material

FIGURE 7: Vegetation monitoring results for the six year monitoring period 2007-2012.

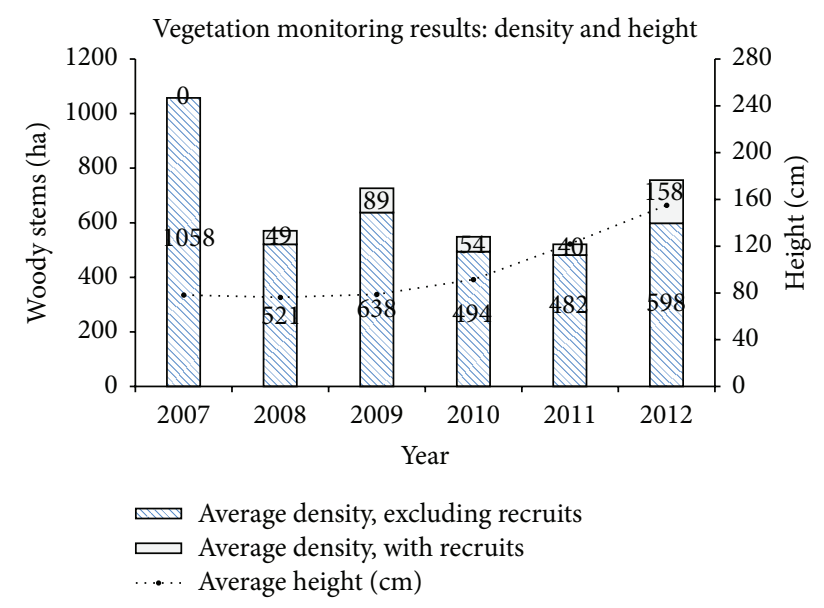

FIGURE 8: Vegetation density and height of woody plants for the sixyear monitoring period 2007-2012.

2011 the percent of survival of planted material appears to be somewhat stable with 2008 at 24\%, 2009 at 30\%, 2010 at 23\%, and 2011 at $33 \%$ survival. The percent of invasive species cover (e.g., Humulus japonicus, Phalaris arundinacea, and Lythrum salicaria) has steadily increased from $32 \%$ in 2007 to $74 \%$ in 2012 (Figure 7). For the four year period from 2008 to 2011 the invasive species was $36 \%, 37 \%, 63 \%$, and $64 \%$, respectively.

Figure 8 represents the average density of woody plants (trees and shrubs) with and without recruits at C1. Figure 8 also illustrates the average height of woody plants for both planted and recruited vegetation. The average density of recruits varies from year to year ranging from zero in 2007 to 158 woody stems/hectare in 2012. The variability observed in this measurement may partly be the result of the simple random sampling procedure where the six plots are different from year to year. In this manner, the observation is not taken within the same sampling plot for the various monitoring points. In Figure 8 the average height of woody plants includes recruits and is increasing from $76 \mathrm{~cm}$ in 2008 , to $79 \mathrm{~cm} \mathrm{2009,} 91 \mathrm{~cm}$ in 2010, $122 \mathrm{~cm}$ in 2011, and $155 \mathrm{~cm}$ in
TABLE 1: Soil features during spring survey period at C1.

\begin{tabular}{lcc}
\hline Monitor year & $\begin{array}{c}\text { Redox features depth range } \\
\text { (centimeters below surface) }\end{array}$ & $\begin{array}{c}\text { Saturation (centimeters } \\
\text { below surface) }\end{array}$ \\
\hline 2007 & Not observed & $5-15^{1}$ \\
2008 & Not observed & Absent \\
2009 & $46-61$ & Absent \\
2010 & $46-61$ & Absent \\
2011 & $46-61$ & $8-10^{1}$ \\
2012 & Not observed & $>61$ \\
\hline
\end{tabular}

${ }^{1}$ Represents above ground surface.

2012. In general, survival of planted trees and shrubs has been low across the site. Average stem density is low, ranging from 522 stems/ha to 756 stems/ha for 2008 to 2012 for both planted material and recruitment. For the sixth year (2012) of monitoring 598 stems/ha were reported. This represents a measurable decline from 1058 stems/ha since the first year (2007) of monitoring.

3.3. Soil Survey. Soils were sampled during spring surveys with six hand-augered soil borings collected to a depth of $61 \mathrm{~cm}$ below grade and evaluated for redoximorphic (redox) features. Table 1 describes the results of the redox and soil saturation assessment over the six year monitoring period observed at $\mathrm{C} 1$. The examination of soil borings resulted in the conclusive presence of redox features between 46 to $61 \mathrm{~cm}$ for years 2009, 2010, and 2011. Redox features were not observed in the hand-augered borings for years 2007, 2008, and 2012. The soils examined were generally consistent with the NRCS description of the Rowland silt loam soils. Typical profiles included a dark brown silty clay loam layer found at variable depths. This layer was sometimes overlaid by a layer of slightly redder soil of varying texture. However, in most cases, the color and texture remained relatively consistent throughout the boring. This Rowland silt loam is alluvial soil and may be described as being formed chiefly from red Triassic shale. The Rowland series range from moderately well to somewhat poorly drained and are located 0.9 to 2.4 meters above normal stream level. During the time since construction of the mitigation project was completed (2006), soils do not appear to be trending towards developing typical wetland soil characteristics, that is, hydric and redoximorphic.

\section{Discussion}

The Soil Survey of Somerset County, New Jersey, [16] indicates that soils within the Finderne mitigation site primarily consist of Rowland silt loam, 0 to 2 percent of slope, frequently flooded (RorAt). Rowland soils are described as deep, moderately well drained and somewhat poorly drained soils located on floodplains along major streams or rivers. These soils are located about three to eight feet above normal stream levels and are subject to frequent stream overflow. The seasonal high water table for the Rowland series is one to three feet below the surface. The 2001 Design Report describes the soil type as silt loam with a hydraulic 
conductivity $\left(K_{s}\right)$ of $16.42 \mathrm{~cm} /$ day. This indicates that there will be minimal water retention (ponding) within the wetland site as a result of losses through seepage. The report stated that the effect of regional ground water table (GWI) is not considered and the contribution of GWI is assumed to be negligible which cannot be modified. Given the soil condition and the lack of ground water inflow, the Finderne site would not be a ground water slope or ground water depression wetland as defined by Novitzki [17]. The major component of water input at the site comes from precipitation (ca. 75\%) but is not retained for extended periods of time. According to Brinson [18] a wetland can be ponded or perched as a function of an impermeable soil layer, but the Finderne site would not be classified as either based on the absences of such a layer. Although there is variability of the hydrology within this site, the general classification may best be described as a surface water depression wetland [17] or stream flooding wetland [18]. A caveat however is that given the variability of the site perhaps it may be inappropriate to designate a single classification.

An adequate water budget with an appropriate hydroperiod is one of the most critical components for a successful mitigation project. There are a variety of complex issues to address, making such projects challenging when developing a water budget. The 2001 Design Report based the surface water inflow on a drainage area of 8.42 ha for the creation forested wetland area of $3.82 \mathrm{ha}(\mathrm{Cl})$. This may have been based on the assumption that the entire Finderne mitigation area of 20.13 ha could be adequately represented as a uniform system using only $3.82 \mathrm{ha}$. This would appear to be an erroneous assumption. The success at Finderne Farms is essentially a function of creating an adequate water budget/hydroperiod by modifying loss due to seepage and surface water inflow. With the application of the NJDEP Water Budget Manual, useful data and graphics that would have enhanced the original design will be used for adaptive management measures. The total Finderne site (52.6 ha) is not an area that has uniform hydrologic conditions and vegetation, and therefore, adaptive management needs to include individual water budgets for the different areas (Figure 2). Future adaptive management efforts can be more effective based on lessons learned from the original project.

A specific range in the monthly change in storage values that produce a sustainable wetland varies as a function of the type of wetland vegetation. The water budget requirements for a forested wetland may be less than an emergent wetland, and in general the hydroperiod will vary as a function of the wetland type. Since precipitation and soil conditions (silt loam) are relatively uniform for this site, it may be adequate to have a generic representative water budget. However, since there is $28 \%$ plant survival in $\mathrm{Cl}$ after six growing seasons (Figure 7) and the overall Finderne site does not satisfy the permit performance standards, it is reasonable to suggest that individual water budgets would be the better approach. It appears that the average monthly change in storage during the growing season (March-October) for the years of record (1972-2001) of $1.8 \mathrm{~cm} / \mathrm{month}$ and three most recent years (1999-2001) with $1.6 \mathrm{~cm} /$ month is inadequate to achieve success for the variable wetland types. In order to satisfy the

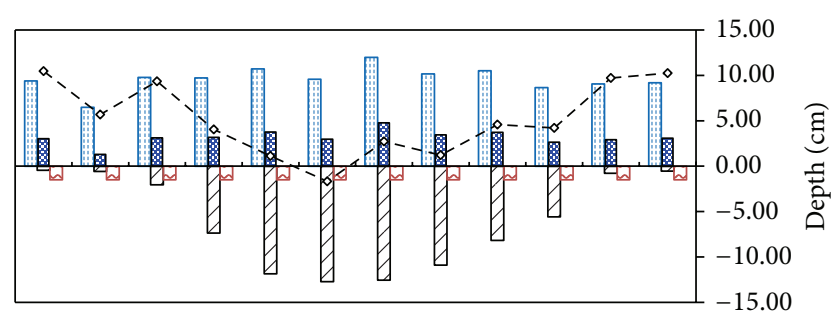

Jan. Feb. Mar. Apr. May. June July Aug. Sept. Oct. Nov. Dec. Months

$$
\begin{array}{ll}
\text { Precipitation } & \text { Surface water inflow } \\
\text { ET } & -\diamond-\Delta S \\
\text { Seepage } &
\end{array}
$$

FIGURE 9: Hypothetical water budget based on assumed maximum loss due to seepage of $1.5 \mathrm{~cm} / \mathrm{month}$. Finderne wetland mitigation site: hypothetical conditions.

required 2:1 ratio of wetland mitigation, modifications must be implemented. The success at Finderne Farms is essentially a function of creating a water budget with an appropriate hydroperiod by potentially increasing surface water inflow and reducing loss due to seepage for the various sites. There may also be an opportunity to exploit overbank inundation events from the Raritan River to enhance input to the water budget.

In order to achieve a stream flooding wetland, modifications would likely involve reducing the elevation and creating swales for channel flow to the interior of the site. The range in annual precipitation from dry year (1976) to wet year (1975) is $96 \mathrm{~cm}$ to $163 \mathrm{~cm}$ with the average conditions for the years of record (1972-2001) of $115 \mathrm{~cm}$. Precipitation varies over time and cannot be controlled, but seepage and surface water inflow may be manipulated through good engineering and design to provide an adequate water budget. If measures are implemented to control seepage (e.g., silt/clay layer), that would limit the rate to $1.5 \mathrm{~cm} / \mathrm{month}$ for the years of record; the hypothetical water budget is illustrated in Figure 9. Only the peak in growing season in the month of June indicates a deficit for change in storage. The change in storage remains positive for the remainder of the growing season.

It is not clear whether a water surface elevation on the Raritan River at the Finderne site of $10.7 \mathrm{~m}$ is adequate (i.e., minimum stage) to achieve inundation of the site. Based on an evaluation of the historical data in the design report, the river appears to have had one overbank flow event from the Raritan River (i.e., 1971, 1974, 1976, 1978, 1982, 1985, 19871998), while in other years there have been more than one event (e.g., 1983, 1984). Based on an analysis of the USGS data, the probability of at least one overbank flow event occurring between March and June in any given year over a 31-year period is $38 \%$ (reflecting one or more events in 12 of 31 years), rather than the $52 \%$ estimated original analysis in 2001. There is a significant gap in overbank events between 1986 and 1999. If only the 16 years of record from 1985 to 2000 were used, there would have been two overbank events or a $13 \%$ chance, compared to a $38 \%$ chance of overbank indicated by the 31-year period. The decrease in probability 
of occurrence suggests that something may have changed in the watershed after 1986 but too little is known to reach such a conclusion. The hydrologic analysis in support of the mitigation design in 2001 indicated that while on-site runoff may contribute some water to the Finderne site, annual overbank, inundation at the site from surface water inflow, is a necessary component for achieving an adequate hydroperiod. The overbank flow appears to be an insignificant contribution to the overall water budget since few weather events occur that cause inundation at the Finderne site. Although the elevation of the site can be reduced as part of adaptive management measures, the retention of water will likely remain an issue unless the soil is modified and seepage is reduced. Not only is it necessary to have a greater frequency of overbank inundation it is also critical to retain water at the site by reducing seepage through soil modification or using a liner/barrier. During the six-year postconstruction monitoring period (2007-2012) soil characterization showed little evidence of development of hydric soils or saturated soil conditions (Table 1).

Based on the U.S. Geological Survey (USGS) stream gage on Raritan River at Manville, NJ (01400500), the closest gaging station, there were a total of 13 overbank events at the Finderne mitigation site between 2007 and 2012 using a threshold of $283.4 \mathrm{~m}^{3} / \mathrm{s}$. This consisted of one event in 2007 (two-day duration), three events in 2008, and one event in 2009 and 2010. There were seven events in 2011 that included a two-day event and a three-day event. There were no overbank events of Raritan River flow in 2012. It appears that the overbank inundation from the Raritan River to the Finderne mitigation site is occurring at a lower frequency than what may be necessary to be consistent with a RorAt soil description. Furthermore, the contribution of overbank events is not likely adding significantly to the overall water budget. The results of the soil surveys performed during the monitoring period also adds credence to this statement, and it is evident that there is not a rapid progression toward a hydric soil with redoximorphic features. Based on results obtained in the 2012 soil investigation, the soil characteristics in the wetland creation areas do not appear to have substantially changed from the 2002 baseline data and they do not correspond to the characteristic of a wetland soil. Additional on-site monitoring of floods may provide useful information to better understand existing patterns of inundation and soil saturation associated with overbank flow events. It appears that in order to receive a beneficial contribution from Raritan River inundation, adaptive management measures will need to include reducing the elevation at the site and/or soil modification to provide better retention of overbank flow. Protection against higher flow velocities in the overbank areas at the Finderne site needs to be a consideration for protection of the target vegetation.

Adaptive management measures are currently being developed and evaluated. The objective of these efforts will be to identify and design measures to improve mitigation wetland hydrology, minimize the negative impacts of large Raritan River overbank events, and at the same time potentially increase the frequency of inundation. Individual water budgets will be developed for each of the distinct areas within the Finderne site which should better represent the variable conditions. Also critical to adaptive management is improving colonization by native vegetation in order to meet the mitigation success criteria at the Finderne site. This wetland mitigation project will be considered successful if, after five full growing seasons, USACE demonstrates that the following four performance standards established in the permit conditions are achieved during the monitoring program.

(1) Compensation Area. That the goals of the wetland mitigation project including areas and the required wetland buffer, as stated in the approved wetland mitigation proposal and the permit, have been satisfied. At the end of the fifth year USACE must submit a field wetland delineation of the wetland mitigation project based on the Federal Manual for Identifying and Delineating Jurisdictional Wetlands (1989), which shows the exact areas of the wetland mitigation areas.

(2) Vegetation. The site has an $85 \%$ survival and $85 \%$ coverage of the mitigation plantings or target hydrophytes which are species native to the area and similar to ones identified on the mitigation planting plan. All plant species in the mitigation area are healthy and thriving. All planted trees are at least 1.5 meters in height.

(3) Invasive Species. The Finderne site is less than $10 \%$ occupied by invasive or noxious species such as, but not limited to, Phragmites australis (common Reed Grass), Typha latifolia (broad-leaved Cattail), Lythrum salicaria (Purple Loosestrife), Berberis thunbergii (Japanese Barberry), Humulus japonica (Japanese hops), and Polygonum cuspidatum (Japanese knotweed).

(4) Hydrology. The proposed hydrologic regime as specified in the mitigation proposal, which proves the mitigation site is a wetland, has been satisfied.

During the six year monitoring period (2007-2012) invasive plant species have increased annually from $32 \%$ cover in 2007 to $74 \%$ in 2012 , while the target species have decreased from $68 \%$ in 2007 to $26 \%$ in 2012 . The success of invasive species is likely hindering the ability of the target species to thrive. It is anticipated that as the target woody species grow taller and become better established, shading would help limit and diminish invasive species. This has not occurred and by the parameters defining success for the Finderne site mitigation credit has not been achieved. The pattern observed in Figure 7 with the percent survival of planted material remaining stable between 2008 and 2012 (24\% and $28 \%$, resp.) may be an indication that woody vegetation has stabilized. Invasive species management has not been successful during the monitoring period of 2007 to 2012. For example, herbicide management in 2009 for Humulus japonicus, Phalaris arundinacea, and Lythrum salicaria has had limited success. Figure 8 illustrates that average height is increasing from 2009 to 2012 which is toward success but 
not to the level required. Success of $85 \%$ survival of native or target woody species has not been achieved.

\section{Conclusions}

The NJDEP Water Budget Manual provided an opportunity to better assess the hydrologic conditions at the Finderne site for the initial mitigation project completed in 2006. From this analysis it appears that the 2001 design does not provide the desired water budget for a sustainable wetland. This postproject analysis of the historical data has been useful in identifying deficiencies in the 2001 Design Report and will aid in planning a more effective adaptive management plan going forward. The future success of this mitigation project and adaptive management measures will be improved with the analysis of individual water budgets for the different enhancement and creation areas. The soil type is within an acceptable range for wetland conditions, although not ideal. The site needs to be modified to induce and sustain an acceptable hydroperiod that would better permit development of hydric soil conditions and promote desired wetland vegetation. Given the current hydrology at the Finderne site a stream flooding wetland does not appear as an appropriate classification. In order to achieve a stream flooding, wetland modifications are necessary, that may include reducing the elevation at the site and involve creating swales for channel flow. The application of the Water Budget Manual and figures generated are useful to explain the Hydrologic Continuity Equation to the nonengineer/nonscientist and as a design tool to facilitate an adequate hydroperiod. Adaptive management measures will be augmented with the application of the NJ DEP Water Budget Manual.

Creation Area 1, designed to be a palustrine forested wetland, remains below compliance with the stated success for hydrology, target vegetation, and hydric soil conditions. Evidence of a successful hydrologic regime has not been observed, and the contribution of Raritan River overbank events has not occurred with an adequate frequency. Overbank inundation events at the site have been inadequate to provide a meaningful hydrologic input to the water budget. This is a deficiency of the design study that may be limiting the success of the vegetation. From 2007 to 2012, there was a general decrease in percent of survival of planted material (49\% to $28 \%$, resp.) and percent of target species (68\% to $26 \%$, resp.). Invasive species should be less than $10 \%$ of the plant community, and there was an observed $74 \%$ in 2012 . These results show that the wetland creation and planting efforts have been trending away from success of meeting $85 \%$ aerial coverage of planted vegetation or target hydrophytes.

\section{Acknowledgments}

The author would like to acknowledge the U.S. Army Corps of Engineers, New York District, for their lead role, and its costsharing partner New Jersey Department of Environmental Protection for making the funding for this mitigation project possible. Mr. Ian Pumo assisted with vegetation figures and
Mr. Mina Mikaeel provided assistance with a review of the literature for wetland mitigation projects.

\section{References}

[1] P. H. Brown and C. L. Lant, "The effect of wetland mitigation banking on the achievement of no-net-loss," Environmental Management, vol. 23, no. 3, pp. 333-345, 1999.

[2] M. S. Race and M. S. Fonseca, "Fixing compensatory mitigation: what will it take?" Ecological Applications, vol. 6, no. 1, pp. 94$101,1996$.

[3] W. Eliot, "Implementing mitigation policies in San Francisco Bay: a Critique, State Coastal Conservancy," Oakland, Calif, USA, 1985.

[4] L. Roberts, "Wetlands trading is a loser's game, say ecologists," Science, vol. 260, pp. 1890-1892, 1993.

[5] R. C. Messaros, G. S. Woolley, M. J. Morgan, and P. S. Rafferty, "Tidal wetlands restoration," in The Functioning of Ecosystems, A. Mahamane, Ed., Intech, Croatia, 2012.

[6] E. A. Hunter, P. A. Rancy, J. P. Gibbs, and D. J. Leopold, "Improving wetland mitigation site identification through community distribution modeling and a patch-based ranking scheme," Wetlands, vol. 32, no. 5, pp. 841-850, 2012.

[7] M. L. Quammen, "Measuring the success of wetlands mitigation," National Wetlands Newsletter, vol. 8, pp. 6-8, 1986.

[8] J. Shisler and D. Charette, "Evaluation of artificial salt marshes in New Jersey," National Wetlands Newsletter, vol. 8, pp. 4-5, 1986.

[9] J. A. Kusler and M. E. Kentula, "Executive summary," in Wetland Creation and Restoration: The Status of the Science, J. A. Kusler and M. E. Kentula, Eds., pp. 17-35, Island Press, Washington, DC, USA, 1990

[10] W. J. Mitsch and J. G. Gosselink, Wetlands, Wiley, Hoboken, NJ, USA, 4th edition, 2007.

[11] National Resources Conservation Service, WETS Table Documentation, Portland, Ore, USA, 1995.

[12] B. J. Petru, C. Ahn, and G. Chescheir, "Alteration of soil hydraulic properties during the construction of mitigation wetlands in the Virginia Piedmont," Ecological Engineering, vol. 51, pp. 140-150, 2013.

[13] G. J. Pierce, Planning Hydrology for Constructed Wetlands, Wetland Training Institute, Poolesville, Md, USA, 1993.

[14] N. Wang, R. Bruins, W. J. Mitsch, and W. T. Acton, Water Budgets of the Two Olentangy River Experimental Wetlands, 1994-1996, School of Natural Resources and Environmental Science Graduate Program. The Ohio State University, 1998.

[15] W. J. Mitsch, X. Wu, R. W. Nairn et al., "Creating and restoring wetlands," BioScience, vol. 48, no. 12, pp. 1019-1030, 1998.

[16] W. C. Kirkham, Ed., National Resources Conservation Service, 1976, United States Department of Agriculture, Soil Conservation Service, Soil Survey of Somerset County, NJ, USA, 1989.

[17] R. P. Novitzki, "Hydrologic characteristics of Wisconsin's wetlands and their influence on floods, stream flow, and sediment," in Wetland Functions and Values - The State of Our Understanding, P. E. Greeson, J. R. Clark, and J. E. Clark, Eds., American Water Resources Association, Minneapolis, Minn, USA, 1979.

[18] M. M. Brinson, "A hydrogeomorphic classification for wetlands," Tech. Rep. WRP-DE-4, U.S. Army Corps of Engineers, Army Engineer Waterways Experiment Station, Vicksburg, Miss, USA, 2008, http://el.erdc.usace.army.mil/wetlands/ pdfs/wrpde4.pdf. 

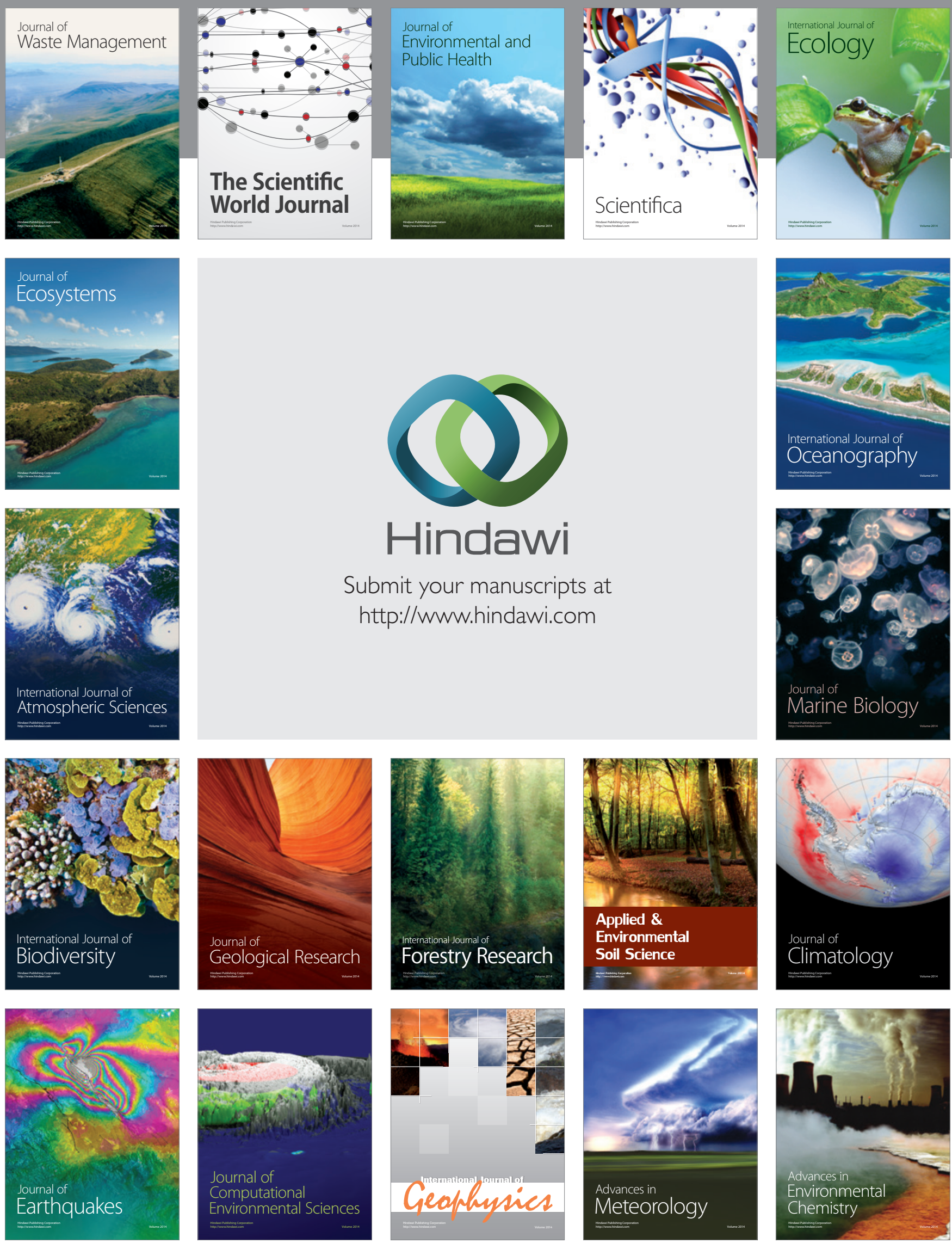